\title{
Novel pharmacological profile of muscarinic receptors mediating contraction of the guinea-pig uterus*
}

\author{
Frank Dörje ${ }^{1, * *}$, Thomas Friebe ${ }^{1}$, Reinhold Tacke ${ }^{2}$, Ernst Mutschler $^{1}$, and Günter Lambrecht ${ }^{1}$ \\ 1 Department of Pharmacology, University of Frankfurt, Theodor-Stern-Kai 7, Gebäude 75 A, D-6000 Frankfurt/M., \\ Federal Republic of Germany \\ 2 Institute of Inorganic Chemistry, University of Karlsruhe, Engesserstrasse, D-7500 Karlsruhe, Federal Republic of Germany
}

Received January 22, 1990/Accepted April 5, 1990

Summary. The present study was designed to further characterize the muscarinic receptors mediating contraction of the guinea-pig uterus. The affinities of various selective muscarinic antagonists were determined and compared with those obtained at $\mathrm{M}_{1}$ (rabbit vas deferens), $M_{2}$ (guinea-pig atria) and $M_{3}$ receptors (guinea-pig ileum).

The contractile responses of uterine smooth muscle from immature guinea-pigs to carbachol $\left(\mathrm{pD}_{2}=5.73\right)$ were competitively antagonized by pirenzepine $\left(\mathrm{pA}_{2}=\right.$ 7.04), AF-DX 116 (11-[[2-[(diethylamino)methyl]-1-piperidinyl]acetyl]-5,11-dihydro-6H-pyrido[2,3-b][1,4]benzo. diazepin-6-one) $\left(\mathrm{pA}_{2}=6.96\right)$, himbacine $\left(\mathrm{pA}_{2}=7.92\right)$, methoctramine $\left(\mathrm{pA}_{2}=7.52\right)$, 4-DAMP (4-diphenylacetoxy-N-methylpiperidine methiodide) $\left(\mathrm{pA}_{2}=8.87\right)$ and sila-hexocyclium $\left(\mathrm{pA}_{2}=8.81\right)$. A comparison of affinity values indicates that the muscarinic receptors present in guinea-pig uterus display a novel pharmacological profile which is not consistent with the presence of either an $M_{1}$, $\mathrm{M}_{2}$ or $\mathrm{M}_{3}$ receptor. The affinities determined for the different antagonists rather showed a close similarity to those obtained at muscarinic receptors present in rat striatum and NG108-15 cells which are considered pharmacological equivalents ( $\mathrm{M}_{4}$ receptors) of the $\mathrm{m} 4$ gene product. We thus hypothesize that the guinea-pig isolated uterus preparation may serve as a simple functional assay system to study the pharmacology of $\mathrm{M}_{4}$ receptors.

Key words: Muscarinic receptors $-\mathrm{M}_{4}$ receptors Guinea-pig uterus - Pirenzepine - Methoctramine Sila-hexocyclium

\footnotetext{
* This work has been presented in part at the Spring Meeting of the German Society for Pharmacology and Toxicology in Mainz, March 1990 (Dörje et al. 1990)

** Present address: Laboratory of Molecular Biology, NINDS, $\mathrm{NIH}$, Bld. 36, Rm. 3D-02, Bethesda MD 20892, USA

Send offprint requests to $\mathrm{F}$. Dörje at the present address
}

\section{Introduction}

Radioligand binding as well as in vitro and in vivo functional studies have revealed the existence of at least three pharmacologically distinct muscarinic receptor subtypes, which have been termed $\mathbf{M}_{1}, \mathbf{M}_{2}$ and $\mathbf{M}_{3}$ (Doods et al. 1987; Mitchelson 1988; Levine and Birdsall 1989). $M_{1}$ receptors are mainly present in neuronal tissues (e.g. autonomic ganglia, cerebral cortex and hippocampus) and are characterized by a high affinity for pirenzepine (affinity profile $M_{1}>M_{3} \geq M_{2}$ ) (Hammer et al. 1980; Hammer and Giachetti 1982). $M_{2}$ and $M_{3}$ receptors are primarily found in lower brain areas and in peripheral effector organs such as heart $\left(\mathrm{M}_{2}\right)$, smooth muscle $\left(\mathrm{M}_{3}\right)$ and glands $\left(\mathrm{M}_{3}\right)$ and display low affinity for pirenzepine. They can be distinguished by the use of selective antagonists such as methoctramine and AF-DX 116 $\left(M_{2}>M_{1}>M_{3}\right)$ (Melchiorre et al. 1987; Waelbroeck et al. 1989; Hammer et al. 1986; Micheletti et al. 1987), himbacine $\left(M_{1} \approx M_{2}>M_{3}\right.$ ) (Gilani and Cobbin 1986; Lazareno and Roberts 1989), sila-hexocyclium ( $\mathbf{M}_{1}$ $\geq \mathrm{M}_{3}>\mathrm{M}_{2}$ ) (Eltze et al. 1988; Waelbroeck et al. 1989), 4-DAMP and hexahydro-sila-difenidol $\left(\mathrm{M}_{3} \geq \mathrm{M}_{1}>\mathrm{M}_{2}\right)$ (Barlow et al. 1976; Mutschler and Lambrecht 1984; Lambrecht et al. 1989).

The pharmacology of the $M_{1}, M_{2}$ and $M_{3}$ receptors closely corresponds to that of the $\mathrm{m} 1, \mathrm{~m} 2$ and $\mathrm{m} 3$ receptor subtypes, respectively, identified by recent receptor cloning studies (Akiba et al. 1988; Buckley et al. 1989). Recombinant DNA technology has also revealed the existence of two additional muscarinic receptor subtypes, $\mathrm{m} 4$ and $\mathrm{m} 5$, whose pharmacology has not been studied in detail so far (Bonner et al. 1987, 1988; Peralta et al. 1987).

Recently, Eglen et al. (1989) suggested that the contractile response to carbachol in the guinea-pig estrogendominated uterus is mediated by a homogenous population of $\mathrm{M}_{2}$ receptors. As smooth muscle contraction is usually mediated by $M_{3}$ receptors (Mitchelson 1988), we have reevaluated this finding using a larger number of selective antagonists. The affinity values obtained in uteri from immature guinea-pigs were compared to those 
obtained at $M_{1}$ receptors in rabbit vas deferens, $M_{2}$ receptors in guinea-pig atria and smooth muscle $\mathrm{M}_{3}$ receptors in guinea-pig ileum. Our data are not consistent with the presence of an $M_{1}, M_{2}$ or $M_{3}$ receptor in the guineapig uterus but suggest that the pharmacology of the uterine muscarinic receptor is most closely related to that present in NG108-15 cells (Michel et al. 1989) and rat striatum (McKinney et al. 1989; Waelbroeck et al. 1990), which is considered the pharmacological correlate $\left(\mathrm{M}_{4}\right.$ receptor) of the $\mathrm{m} 4$ gene product.

\section{Methods}

Guinea-pig isolated uterus. Immature guinea-pigs (Pirbright-white, $190-220 \mathrm{~g}, 3-4$ weeks old) were killed by a blow on the head and uterine horns were excised and separated from fat deposits and mesenteric attachments. Uterine horns were suspended under $1.0 \mathrm{~g}$ tension in $7 \mathrm{ml}$ tissue baths containing oxygenated $\left(95 \% \mathrm{O}_{2}+5 \%\right.$ $\mathrm{CO}_{2}$ ) Sund's physiological salt solution (mmol/l: $\mathrm{NaCl} 154.0, \mathrm{KCl}$ 5.63, $\mathrm{CaCl}_{2} 0.54, \mathrm{MgCl}_{2} 0.95, \mathrm{NaHCO}_{3} 5.95$, (+)-glucose 2.78). The preparations were maintained at $30^{\circ} \mathrm{C}$ and after $1 \mathrm{~h}$ equilibration period, isotonic contractions to carbachol were recorded by a forcedisplacement transducer connected to a Hellige amplifier and a Rikadenki multichannel recorder. Initially, the tissues were exposed to a single concentration of carbachol $(3 \mu \mathrm{mol} / 1)$ to check the responsiveness to the agonist. Then two cumula tive concentration-response curves to carbachol were constructed, one in the absence and one in the presence of antagonist. In separate control experiments, no significant changes in tissue sensitivity to the agonist was observed over the period necessary for the determination of two concentration-response curves.
\end{abstract}

Rabbit isolated vas deferens. Experiments on rabbit isolated vas deferens were performed according to Eltze (1988). Male New Zealand white rabbits $(2.5-3.0 \mathrm{~kg})$ were killed by i.v. injection of $120 \mathrm{mg} / \mathrm{kg}$ pentobarbitone sodium. Vasa deferentia were excised and divided into four segments of approximately $1.5 \mathrm{~cm}$ length. The preparations were set up in $7 \mathrm{ml}$ organ baths containing modified Krebs buffer which consisted of $(\mathrm{mmol} / \mathrm{I}): \mathrm{NaCl} 118.0, \mathrm{KCl} 4.7$, $\mathrm{CaCl}_{2} 1.8, \mathrm{MgSO}_{4} 0.6, \mathrm{KH}_{2} \mathrm{PO}_{4} 1.2, \mathrm{NaHCO}_{3} 25.0$ and (+)-glucose $11.1 ; 1 \mu \mathrm{mol} / \mathrm{l}$ yohimbine was included to block $\alpha_{2}$-adrenoceptors. The bathing fluid was maintained at $31^{\circ} \mathrm{C}$ and aerated with $95 \%$ $\mathrm{O}_{2}+5 \% \mathrm{CO}_{2}$. A basal tension of $750 \mathrm{mg}$ was applied. After a 30 min equilibration period twitch contractions were elicited by field stimulation $(0.05 \mathrm{~Hz}, 0.5 \mathrm{~ms}, 30 \mathrm{~V})$ with platinum electrodes and recorded as described for the isolated uterus. The neurogenic twitch contractions were concentration-dependently inhibited by the $M_{1}$ receptor agonist 4-Cl-McN-A-343 [4-(4-chlorophenylcarbamoyloxy)-2-butynyltrimethylammonium iodide] (Eltze et al. 1988). After $1 \mathrm{~h}$ equilibration period, concentration-response curves were constructed by adding doses of 4-Cl-McN-A-343 cumulatively. When these responses were constant, concentration-response curves were repeated in the presence of antagonists.

Guinea-pig isolated atria and ileum. Guinea-pigs (Pirbright-white, $300-400 \mathrm{~g}$ ) of either sex were killed by cervical dislocation. Left atria and ileal longitudinal muscle strips (Paton and Zar 1968) were set up in $6 \mathrm{ml}$ organ baths, under $500 \mathrm{mg}$ tension, in oxygenated $\left(95 \% \mathrm{O}_{2}+5 \% \mathrm{CO}_{2}\right)$ Tyrode solution $\left(32^{\circ} \mathrm{C}\right)$ composed of $(\mathrm{mmol} /$ 1): $\mathrm{NaCl} 137.0, \mathrm{KCl} 2.7, \mathrm{CaCl}_{2} 1.8, \mathrm{MgCl}_{2} 1.05, \mathrm{NaHCO}_{3}$ 11.9, $\mathrm{NaH}_{2} \mathrm{PO}_{4} 0.42$ and $(+)$-glucose 5.6. Arecaidine propargyl ester (Moser et al. 1989) was used as an agonist. Atria were paced electrically $(2 \mathrm{~Hz}, 3 \mathrm{~ms}, 5 \mathrm{~V})$ by means of platinum electrodes. Negative inotropic effects to the agonist were measured as changes in isometric tension. Responses of ileal longitudinal muscle to arecaidine propargyl ester were measured as isotonic contractions. Atrial and ileal responses were recorded as with the isolated uterus. After an $1 \mathrm{~h}$ equilibration period, concentration-response curves to arecaidine propargyl ester were obtained by use of cumulative dosing. When two control curves were superimposable, cumulative concentration-response curves were repeated in the presence of antagonists.

Antagonist affinities. Three to four different concentrations of each antagonist (log conc. intervals $=0.5$ ) were used. Antagonists were allowed to equilibrate for $15-30 \mathrm{~min}$ (ileum and uterus), 30$45 \mathrm{~min}$ (atria) or $30-60 \mathrm{~min}$ in vas deferens, respectively. Preliminary experiments indicated that these intervals were sufficient for equilibration of the antagonist concentrations used. The uterus preparation was exposed to only one concentration of antagonist. $\mathrm{EC}_{50} 0^{-v a l u e s}$ of agonists in the absence and presence of antagonists were determined graphically for calculation of dose-ratios. The slopes of Arunlakshana-Schild plots (Arunlakshana and Schild 1959) were determined by linear regression by the method of least squares. $\mathrm{pA}_{2}$-values were estimated as the intercept on the abscissa scale by fitting to the data the best straight line with a slope of unity (Tallarida and Murray 1986).

Statistical evaluation. The data are presented as means \pm SEM of $n$ experiments. Differences between mean values were tested for statistical significance by Student's $t$-test; $p<0.05$ was accepted as being significant.

Drugs. The following drugs were used: carbamoylcholine chloride, tetrodotoxin and yohimbine hydrochloride (Sigma, München, FRG); hexamethonium bromide (Fluka, Buchs, Switzerland); pirenzepine dihydrochloride and AF-DX 116 (11-[[2-[(diethylamino)methyl]-1 - piperidinyl]acetyl]-5,11 -dihydro-6H-pyrido[2,3b] $[1,4]$ benzodiazepin - 6 -one)(Thomae, Biberach, FRG); himbacine hydrochloride (kindly donated by Dr. W. C. Taylor, Sydney, Australia); methoctramine tetrahydrochloride (generous gift from Dr. C. Melchiorre, Bologna, Italy); 4-DAMP (4-diphenylacetoxy-Nmethylpiperidine methiodide) (kindly donated by Dr. R. B. Barlow, Bristol, UK); sila-hexocyclium methyl sulfate (Tacke et al. 1989), 4 - (4 - chlorophenylcarbamoyloxy) - 2 - butynyltrimethylammonium iodide (4-Cl-McN-A343) (Nelson et al. 1976) and arecaidine propargyl ester (Mutschler and Hultzsch 1973) were synthesized in our laboratories. All other chemicals were of reagent grade and used as purchased.

\section{Results}

The contractile responses of the isolated guinea-pig uterus to carbachol were not significantly $(P>0.05)$ affected by the presence of tetrodotoxin $(1 \mu \mathrm{mol} / \mathrm{l})$ or hexamethonium $(10 \mu \mathrm{mol} / \mathrm{l})$, excluding the involvement of neuronal nicotinic or muscarinic receptors (data not shown).

All antagonists employed concentration-dependently inhibited the carbachol-induced contractile responses of the isolated guinea-pig uterus $\left(-\log \mathrm{EC}_{50}=5.73 \pm 0.03\right)$ (Fig. 1) as well as the negative inotropic responses in guinea-pig atria $\left(-\log \mathrm{EC}_{50}=8.12 \pm 0.07\right)$ and ileal contractions $\left(-\log \mathrm{EC}_{50}=7.77 \pm 0.04\right)$ to arecaidine propargyl ester. Likewise, the 4-Cl-McN-A-343-induced inhibition of twitch contractions of the rabbit vas deferens $\left(-\log \mathrm{EC}_{50}=7.12 \pm 0.06\right)$ was concentrationdependently blocked by all antagonists examined. In all tissues, parallel shifts of the agonist concentration-response curves without any appreciable changes of basal tension or reduction of maximum responses were observed. This is shown for pirenzepine, methoctramine and 

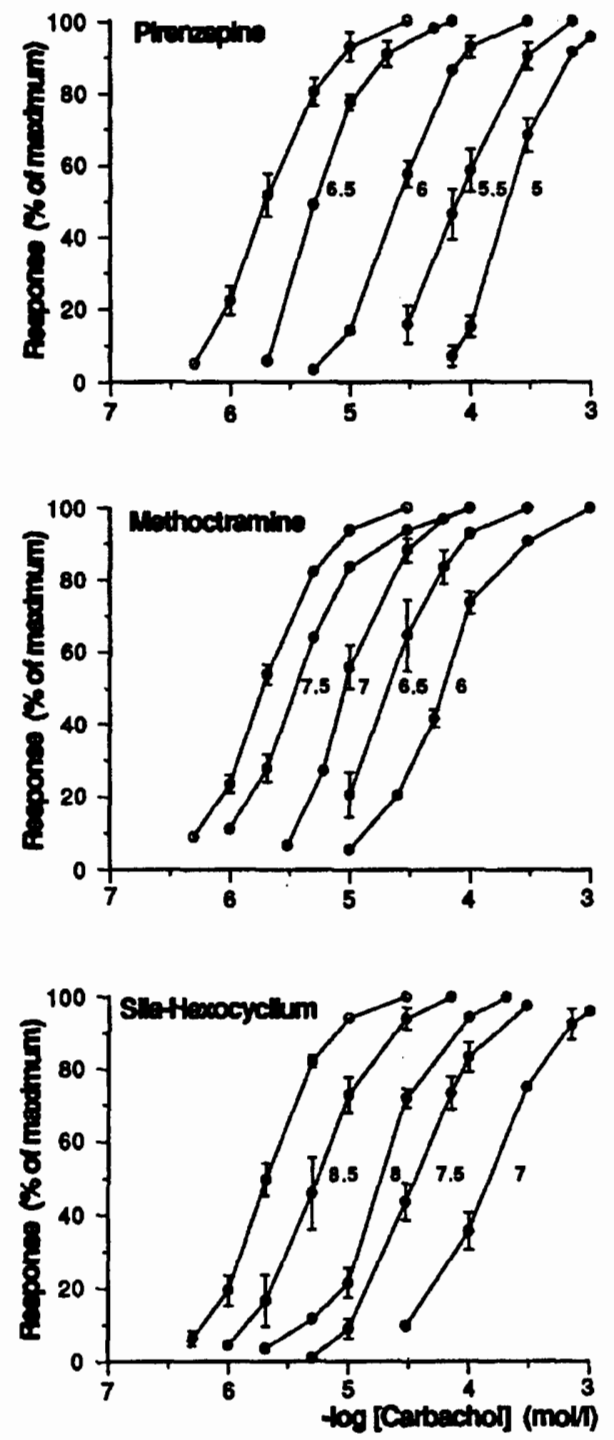

Fig. 1. Cumulative concentration-response curves for carbacholinduced contractions of the guinea-pig uterus in the absence $(O)$ and presence $(\theta)$ of increasing concentrations of pirenzepine, methoctramine and sila-hexocyclium. Numbers next to the concentration-response curves indicate - log molar antagonist concentrations. Contractile responses to each concentration of agonist are expressed as a percentage of the maximum contraction induced by carbachol. The data points represent mean of $n=3-5$ observations (SEM are given as vertical bars if larger than symbol size)

sila-hexocyclium in Fig. 1. Arunlakshana-Schild plots were linear through the concentration range tested for each antagonist and slopes were not significantly different from unity $(p>0.05)$ (Table 1$)$. Thus, all compounds behaved as competitive muscarinic antagonists in all preparations used. The $\mathrm{pA}_{2}$-values determined for the various antagonists are shown in Table 1 . As indicated, some data are taken from work previously published (Lambrecht et al. 1989; Waelbroeck et al. 1989). A comparison of $\mathrm{pA}_{2}$ values reveals that the antagonist affinities obtained at uterine muscarinic receptors of the guinea-pig do not correlate well with those determined at $M_{1}, M_{2}$ or $M_{3}$ receptors (Table 1, Fig. $2 \mathrm{~A}-\mathrm{C}$ ).

\section{Discussion}

Receptor binding studies suggest that smooth muscle of the ileum (Giraldo et al. 1988), urinary. bladder (Monferini et al. 1988) and trachea (Roffel et al. 1989) have both $\mathrm{M}_{2}$ and $\mathrm{M}_{3}$ receptors. Functionally, however, smooth muscle contraction appears to be mediated through $\mathrm{M}_{3}$ receptors only (Mitchelson 1988). In contrast to these reports, Eglen et al. (1989) suggested that the muscarinic receptor mediating smooth muscle contraction of the guinea-pig uterus is of the $\mathrm{M}_{2}$ type. We have reevaluated this controversial finding using a larger number of selective antagonists. The affinities obtained at uterine muscarinic receptors of immature guinea-pigs were compared to those determined at $\mathbf{M}_{1}$ (rabbit vas deferens), $\mathbf{M}_{2}$ (guinea-pig atria) and $\mathbf{M}_{3}$ receptors (guinea-pig ileum).

The antimuscarinic potencies of the antagonists at $\mathrm{M}_{1}, \mathrm{M}_{2}$ and $\mathrm{M}_{3}$ receptors ( $\mathrm{pA}_{2}$-values, Table 1) were in good agreement with their affinity estimates determined in radioligand binding studies (Lazareno and Roberts 1989; Waelbroeck et al. 1989) and previous functional studies (Barlow et al. 1976; Gilani and Cobbin 1986; Micheletti et al. 1987; Eltze 1988; Eltze et al. 1988; Waelbroeck et al. 1989; Lambrecht et al. 1989). A comparison of these affinity values with those determined at uterine muscarinic receptors suggests that the muscarinic receptor mediating contractions of the guinea-pig uterus is pharmacologically unique (Table 1). As discussed below, its profile is not consistent with the presence of an $M_{1}, M_{2}$ or $M_{3}$ receptor in this tissue. Moreover, since the slopes of Arunlakshana-Schild regression lines did not significantly differ from unity, the presence of a heterogeneous mixture of these subtypes appears to be unlikely (Table 1). This conclusion is further supported by radioligand binding studies which have identified a homogeneous population of muscarinic binding sites in the guinea-pig uterus (Eglen et al. 1989).

The affinity of pirenzepine $\left(\mathrm{pA}_{2}=7.04\right)$ for uterine muscarinic receptors was 16 -fold lower than that observed at $M_{1}$ receptors in vas deferens, excluding the presence of $M_{1}$ receptors (Table 1, Fig. 2A). Furthermore, uterine muscarinic receptors displayed high affinity for AF-DX $116\left(\mathrm{pA}_{2}=6.96\right)$, himbacine $\left(\mathrm{pA}_{2}=7.92\right)$ and methoctramine $\left(\mathrm{pA}_{2}=7.52\right)$. Their $\mathrm{pA}_{2}$-values closely approached those obtained in guinea-pig atria (Fig. 2B) but were 3-, 4- and 24-fold higher, respectively, than observed at ileal $M_{3}$ receptors (Fig. $2 C$ ). These data, in conjunction with the low affinity found for pirenzepine, would indicate a high similarity of the uterine receptors to cardiac $\mathrm{M}_{2}$ receptors. However, the high antimuscarinic potencies of the selective antagonists 4 DAMP $\left(\mathrm{pA}_{2}=8.87\right)$ and sila-hexocyclium $\left(\mathrm{pA}_{2}=8.81\right)$ do not fit into this concept. These antagonists show a 3and 17-fold higher affinity for muscarinic receptors in the uterus than for atrial $\mathrm{M}_{2}$ receptors (Fig. 2B). 
Table 1. $\mathrm{pA}_{2}$-values and slopes of Arunlakshana-Schild plots (in parentheses) for various selective muscarinic antagonists at $M_{1}, M_{2}, M_{3}$ and guinea-pig uterine muscarinic receptors

\begin{tabular}{|c|c|c|c|c|}
\hline Compound & $\begin{array}{l}\text { Rabbit vas } \\
\text { deferens }\left(M_{1}\right)\end{array}$ & $\begin{array}{l}\text { Guinea-pig } \\
\text { atria }\left(\mathrm{M}_{2}\right)\end{array}$ & $\begin{array}{l}\text { Guinea-pig } \\
\text { ileum }\left(M_{3}\right)\end{array}$ & $\begin{array}{l}\text { Guinea-pig } \\
\text { uterus }\end{array}$ \\
\hline Pirenzepine & $\begin{array}{l}8.24 \pm 0.06^{*} \\
(1.19 \pm 0.10)\end{array}$ & $\begin{array}{l}6.82 \pm 0.03^{*} \\
(0.98 \pm 0.02)\end{array}$ & $\begin{array}{l}6.88 \pm 0.04^{*} \\
(1.07 \pm 0.04)\end{array}$ & $\begin{array}{l}7.04 \pm 0.02 \\
(1.00 \pm 0.03) \\
{[n=14 ; 14]}\end{array}$ \\
\hline AF-DX 116 & $\begin{array}{l}7.12 \pm 0.04 \\
(1.07 \pm 0.08) \\
{[n=8 ; 4]}\end{array}$ & $\begin{array}{l}7.36 \pm 0.05 \\
(0.89 \pm 0.08) \\
{[n=8 ; 8]}\end{array}$ & $\begin{array}{l}6.48 \pm 0.04 \\
(0.93 \pm 0.07) \\
{[n=10 ; 9]}\end{array}$ & $\begin{array}{l}6.96 \pm 0.03 \\
(0.92 \pm 0.05) \\
{[n=12 ; 12]}\end{array}$ \\
\hline Himbacine & $\begin{array}{l}8.17 \pm 0.04 \\
(1.02 \pm 0.06) \\
{[n=13 ; 7]}\end{array}$ & $\begin{array}{l}8.09 \pm 0.04 \\
(0.86 \pm 0.07) \\
{[n=8 ; 8]}\end{array}$ & $\begin{array}{l}7.34 \pm 0.05 \\
(0.93 \pm 0.08) \\
{[n=8 ; 4]}\end{array}$ & $\begin{array}{l}7.92 \pm 0.03 \\
(0.99 \pm 0.05) \\
{[n=19 ; 19]}\end{array}$ \\
\hline Methoctramine & $\begin{array}{l}6.85 \pm 0.07^{*} \\
(1.19 \pm 0.10)\end{array}$ & $\begin{array}{l}7.69 \pm 0.03^{*} \\
(1.05 \pm 0.05)\end{array}$ & $\begin{array}{l}6.17 \pm 0.05^{*} \\
(0.99 \pm 0.09)\end{array}$ & $\begin{array}{l}7.51 \pm 0.03 \\
(0.97 \pm 0.04) \\
{[n=15 ; 15]}\end{array}$ \\
\hline 4-DAMP & $\begin{array}{l}9.39 \pm 0.06 \\
(1.09 \pm 0.12) \\
{[n=8 ; 6]}\end{array}$ & $\begin{array}{l}8.40 \pm 0.05 \\
(0.93 \pm 0.08) \\
{[n=8 ; 8]}\end{array}$ & $\begin{array}{l}9.34 \pm 0.05 \\
(0.91 \pm 0.05) \\
{[n=8 ; 8]}\end{array}$ & $\begin{array}{l}8.87 \pm 0.01 \\
(1.01 \pm 0.02) \\
{[n=18 ; 18]}\end{array}$ \\
\hline Sila-Hexocyclium & $\begin{array}{l}9.04 \pm 0.03 \\
(1.07 \pm 0.06) \\
{[n=8 ; 6]}\end{array}$ & $\begin{array}{l}7.57 \pm 0.04^{* *} \\
(0.94 \pm 0.07)\end{array}$ & $\begin{array}{l}8.78 \pm 0.05^{* *} \\
(1.04 \pm 0.09)\end{array}$ & $\begin{array}{l}8.81 \pm 0.03 \\
(0.97 \pm 0.05) \\
{[n=16 ; 16]}\end{array}$ \\
\hline
\end{tabular}

The data are presented as means \pm SEM. The slopes of Arunlakshana-Schild plots were calculated by linear regression analysis (Tallarida and Murray 1986). $\mathrm{pA}_{2}$-values were obtained after the unity constraint had been imposed. The number of total data points $(n)$ and tissues used are given in square brackets. The slopes shown are not significantly different from unity $(p>0.05) .{ }^{*}$ Data taken from Lambrecht et al. $1989 ;{ }^{* *}$ Data previously published (Waelbroeck et al. 1989)
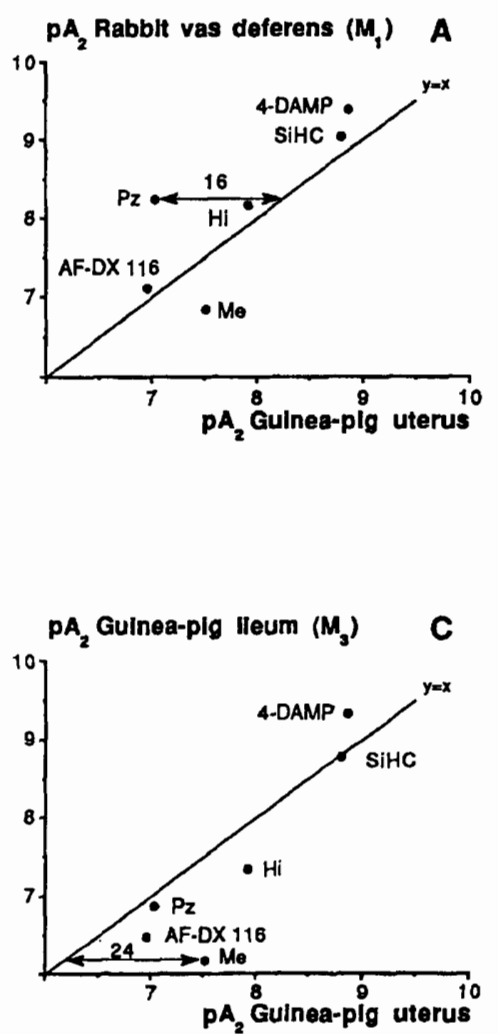
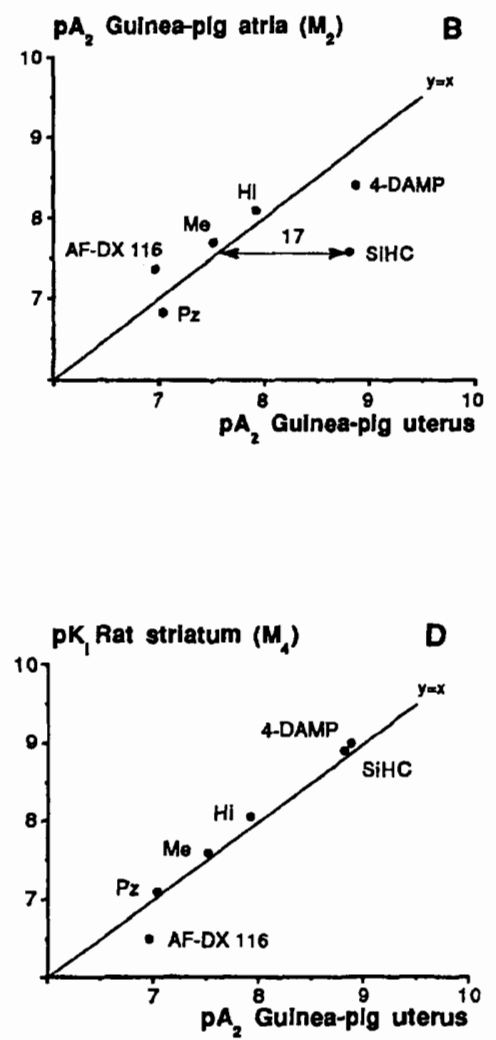

Fig. 2 A-D. Comparison of mean antagonist affinities ( $\mathrm{pA}_{2}$-values, Table 1) obtained for pirenzepine (Pz), AF-DX 116, himbacine (Hi), methoctramine (Me), 4-DAMP and silahexocyclium (Sihc) at muscarinic receptors in guinea-pig uterus to their affinity estimates determined at $M_{1}(A), M_{2}(B)$ and $M_{3}(C)$ receptors. Comparison of mean antagonist affinities ( $\mathrm{pA}_{2}$ - or $\mathrm{pK}_{\mathrm{i}}$-values) obtained in functional studies in guinea-pig uterus and radioligand binding assays at $M_{4}$ receptors present in rat striatum (Waelbroeck et al. 1990), (D). In case of receptor identity, the data points should not significantly deviate from the theoretical equality line $(y=x)$. The distance to this line (given in Fig. 2A-C for pirenzepine, sila-bexocyclium and methoctramine as the antilog of the difference in $\mathrm{pA}_{2}$-values) is a direct measure of receptor selectivity 
Taken together, the muscarinic receptors present in guinea-pig uterus display a novel pharmacological profile whose most characteristic features are a low affinity for pirenzepine but high affinity for methoctramine and silahexocyclium.

Recent findings suggest that the muscarinic receptors in rat striatum (McKinney et al. 1989; Waelbroeck et al. 1990) and NG108-15 cells (Michel et al. 1989; Baumgold and White 1989) are pharmacological equivalents $\left(\mathrm{M}_{4}\right.$ receptors) of the $\mathrm{m} 4$ gene (Brann et al. 1988; Peralta et al. 1987). In Fig. 2D, antagonist affinities ( $\mathrm{pA}_{2}$-values) for muscarinic receptors in guinea-pig uterus are plotted against their binding affinities ( $\mathrm{pK}_{\mathrm{i}}$-values) for $\mathrm{M}_{4}$ receptors in rat striatum (Waelbroeck et al. 1990). Conspicuously, the affinity estimates of the antagonists obtained in guinea-pig uterus and rat striatum were strikingly similar. In addition, the binding affinities of pirenzepine, AFDX 116, methoctramine and 4-DAMP at $\mathrm{M}_{4}$ receptors in NG108-15 cells (Michel et al. 1989) correlate well with their functional potencies in the guinea-pig uterus (this study).

Biochemical studies with NG108-15 cells (Harden et al. 1986) and cloned muscarinic receptors (Peralta et al. 1988; Ashkenazi et al. 1989) revealed that $\mathrm{m} 4$ receptors strongly inhibit adenylate cyclase. Moreover, m4 receptors have also been shown to mediate stimulation of phosphoinositide hydrolysis (Peralta et al. 1988; Ashkenazi et al. 1989). Both second messenger responses have been reported to occur upon muscarinic stimulation of the immature guinea-pig uterus (Leiber et al. 1984; Marc et al. 1986).

We therefore hypothesize that the isolated guinea-pig uterus preparation may serve as a simple functional assay system to study the pharmacology of $\mathrm{M}_{4}$ receptors. To lend further support to this notion, molecular biological studies are underway to verify that $\mathrm{m} 4 \mathrm{mRNA}$ is in fact expressed in this tissue.

Acknowledgements. The authors would like to thank Mr. W. Kujath and Dr. U. Albus (Hoechst AG, Frankfurt/M., FRG) for helpful advice. We also appreciate the helpful comments on the manuscript contributed by Dr. J. Wess. The expert technical assistance of Mrs. M. Wagner-Röder is gratefully acknowledged. G. L., E. M. and R. T. thank the Fonds der Chemischen Industrie and the Deutsche Forschungsgemeinschaft for financial support. F. D. was supported by a Kékulé-scholarship from the Stiftung Stipendien-Fonds des Verbandes der Chemischen Industrie.

\section{References}

Akiba I, Kubo T, Maeda A, Bujor J, Nakai J, Mishina M, Numa $S$ (1988) Primary structure of porcine muscarinic acetylcholine receptor III and antagonist binding studies. FEBS Lett 235:257-261

Ashkenazi A, Peralta EG, Winslow JW, Ramachandran J, Capon DJ (1989) Functional diversity of muscarinic receptor subtypes in cellular signal transduction and growth. Trends Pharmacol Sci Suppl 10:16-22

Arunlakshana O, Schild HO (1959) Some quantitative uses of drug antagonists. Br J Pharmacol 14:48-58

Barlow RB, Berry KJ, Glenton PAM, Nikolaou NM, Soh KS (1976) A comparison of affinity constants for muscarinic-sensitive acetylcholine receptors in guinea-pig atrial pacemaker cells at $29^{\circ} \mathrm{C}$ and in ileum at $29^{\circ} \mathrm{C}$ and $37^{\circ} \mathrm{C}$. Br J Pharmacol 58:613620

Baumgold J, White TH (1989) Pharmacological differences between muscarinic receptors coupled to phosphoinositide turnover and those coupled to adenylate cyclase inhibition. Biochem Pharmacol 38:1605-1616

Bonner TI, Buckley NJ, Young AC, Brann MR (1987) Identification of a family of muscarinic acetylcholine receptor genes. Science $237: 527-532$

Bonner TI, Young AC, Buckley NJ (1988) Cloning and expression of the human and rat $\mathrm{m} 5$ muscarinic acetylcholine receptor genes. Neuron 1:403-410

Brann MR, Buckley NJ, Bonner TI (1988) The striatum and cerebral cortex express different muscarinic receptor mRNAs. FEBS Lett 230:90-94

Buckley NJ, Bonner TI, Buckley CM, Brann MR (1989) Antagonist binding properties of five cloned muscarinic receptors expressed in CHO-K1 cells. Mol Pharmacol 35:469-476

Doods HN, Mathy M-J, Davidesko D, van Charldorp KJ, de Jonge A, van Zwieten PA (1987) Selectivity of muscarinic antagonists in radioligand and in vivo experiments for the putative $M_{1}, M_{2}$ and $\mathrm{M}_{3}$ receptors. $J$ Pharmacol Exp Ther 242:257-262

Dörje F, Friebe T, Tacke R, Mutschler E, Lambrecht G (1990) Pharmacological characterization of muscarinic receptors mediating contractions of guinea-pig uterus. Naunyn-Schmiedeberg's Arch Pharmacol 341: Suppl. R79 (abstract)

Eglen RM, Michel AD, Whiting RL (1989) Characterisation of the muscarinic receptor subtype mediating contractions of the guinea-pig uterus. Br J Pharmacol 96:497-499

Eltze M (1988) Muscarinic M1- and M2-receptors mediating opposite effects on neuromuscular transmission in rabbit vas deferens. Eur J Pharmacol 151:205-221

Eltze M, Gmelin G, Wess J, Strohmann C, Tacke R, Mutschler E, Lambrecht G (1988) Presynaptic muscarinic receptors mediating inhibition of neurogenic contraction in rabbit vas deferens are of the ganglionic $\mathrm{M}_{1}$-type. Eur $\mathrm{J}$ Pharmacol $158: 233-242$

Gilani SAH, Cobbin LB (1986) The cardio-selectivity of himbacine: a muscarinic receptor antagonist. Naunyn-Schmiedeberg's Arch Pharmacol 332:16-20

Giraldo E, Vigano MA, Hammer R, Ladinsky H (1988) Characterization of muscarinic receptors in guinea-pig ileum longitudinal smooth muscle. Mol Pharmacol 33:617-625

Hammer R, Berrie CP, Birdsall NJM, Burgen ASV, Hulme EC (1980) Pirenzepine distinguishes between different subclasses of muscarinic receptors. Nature 283:90-92

Hammer R, Giachetti A (1982) Muscarinic receptor subtypes: M1 and $M 2$, biochemical and functional characterization. Life Sci $31: 2991-2998$

Hammer R, Giraldo E, Schiavi GB, Montagna E, Ladinsky H (1986) Binding profile of a novel cardioselective muscarinic receptor antagonist, AF-DX 116, to membranes of peripheral tissues and brain in the rat. Life Sci 38:1653-1662

Harden TK, Tanner LI, Martin MW, Nakahata N, Hughes AR, Helper JR, Evans T, Masters SB, Brown JH (1986) Characteristics of two biochemical responses to stimulation of muscarinic cholinergic receptors. Trends Pharmacol Sci Suppl. 7:14-18

Lambrecht G, Feifel R, Wagner-Röder M, Strohmann C, Zilch H, Tacke R, Waelbroeck M, Christophe J, Boddeke H, Mutschler E (1989) Affinity profiles of hexahydro-sila-difenidol analogues at muscarinic receptor subtypes. Eur J Pharmacol 168:71-80

Lazareno S, Roberts FF (1989) Functional and binding studies with muscarinic $\mathrm{M}_{2}$-subtype selective antagonists. $\mathrm{Br} J$ Pharmacol 98:309-317

Leiber D, Harbon S, Guillet J-G, André C, Strosberg AD (1984) Monoclonal antibodies to purified muscarinic receptor display agonist-like activity. Proc Natl Acad Sci USA 81:4331 - 4334

Levine RR, Birdsall NJM (eds) (1989) Subtypes of muscarinic receptors IV. Trends Pharmacol Sci Suppl 10:1-119

Marc S, Leiber D, Harbon S (1986) Carbachol and oxytocin stimulate the generation of inositol phosphates in the guinea-pig myometrium. FEBS Lett 201:9-14 
McKinney M, Anderson D, Forray C, El-Fakahany EE (1989) Characterisation of the striatal $\mathrm{M}_{2}$ muscarinic receptor mediating inhibition of cyclic AMP using selective antagonists: a comparison with the brainstem $\mathrm{M}_{2}$ receptor. J Pharmacol Exp Ther 250:565-572

Melchiorre C, Angeli P, Lambrecht G, Mutschler E, Picchio MT, Wess J (1987) Antimuscarinic action of methoctramine, a new cardioselective $\mathrm{M}_{2}$ muscarinic antagonist alone and in combination with atropine and gallamine. Eur J Pharmacol 144:117124

Micheletti R, Montagna E, Giachetti A (1987) AF-DX 116, a cardioselective muscarinic antagonist. J Pharmacol Exp Ther $241: 628-634$

Michel AD, Delmondo R, Stefanich E, Whiting RL (1989) Binding characteristics of the muscarinic receptor subtype of the NG 108-15 cell line. Naunyn-Schmiedeberg's Arch Pharmacol $340: 62-67$

Mitchelson F (1988) Muscarinic receptor differentiation. Pharmacol Ther 37:357-423

Monferini E, Giraldo E, Ladinsky H (1988) Characterization of the muscarinic receptor subtypes in the rat urinary bladder. Eur $\mathrm{J}$ Pharmacol 147:453-458

Moser U, Lambrecht G, Wagner M, Wess J, Mutschler E (1989) Structure-activity relationship of new analogues of arecaidine propargyl ester at muscarinic $\mathrm{M}_{1}$ and $\mathrm{M}_{2}$ receptor subtypes. $\mathrm{Br}$ J Pharmacol 96:319-324

Mutschler E, Hultzsch K (1973) Über Struktur-Wirkungs-Beziehungen von ungesättigten Estern des Arecaidins und Dihydroarecaidins. Arzneimittelforschung 23:732-737

Mutschler E, Lambrecht G (1984) Selective muscarinic agonists and antagonists in functional tests. Trends Pharmacol Sci Suppl $5: 39-44$

Nelson WL, Freeman DS, Vinzenzi FF (1976) Stereochemical analogs of a muscarinic, ganglionic stimulant, 2 . Cis and trans olefinic, epoxide, and cyclopropane analogs related to 4-[N-(3chlorophenyl) carbamoyloxy] - 2 - butynyltrimethylammonium chloride (McN-A-343). J Med Chem 19:153-158

Paton WDM, Zar MA (1968) The origin of acetylcholine release from guinea-pig intestine and longitudinal muscle strips. J Physiol 194:13-33

Peralta EG, Ashkenazi A, Winslow JW, Smith DH, Ramachandran J, Capon DJ (1987) Distinct primary structures, ligand-binding properties and tissue-specific expression of four human muscarinic acetylcholine receptors. EMBO J 6:3923-3929

Peralta EG, Ashkenazi A, Winslow JW, Ramachandran J, Capon DJ (1988) Differential regulation of PI hydrolysis and adenylyl cyclase by muscarinic receptor subtypes. Nature 334:434-437

Roffel AF, Elzinga CRS, Meurs H, Zaagsma J (1989) Allosteric interactions of three muscarinic antagonists at bovine tracheal smooth muscle and cardiac $\mathrm{M}_{2}$ receptors. Eur J Pharmacol Mol Pharmacol Sect 172:61 - 70

Tacke R, Linoh H, Rafeiner K, Lambrecht G, Mutschler E (1989) Synthesis and properties of the selective antimuscarinic agent sila-hexocyclium methyl sulfate. J Organomet Chem 359:159168

Tallarida RJ, Murray RB (1986) Manual of pharmacologic calculations with computer programs. Sec ed, Springer, Berlin Heidelberg New York Tokyo

Waelbroeck M, Tastenoy M, Camus J, Christophe J, Strohmann C, Linoh H, Zilch H, Tacke R, Mutschler E, Lambrecht G (1989) Binding and functional properties of antimuscarinics of the hexocyclium/sila-hexocyclium and hexahydro-diphenidol/ hexahydro-sila-diphenidol type to muscarinic receptor subtypes. Br J Pharmacol 98:197-205

Waelbroeck M, Camus J, Tastenoy M, Christophe J (1990) Identification of the striatum " $B$ " sites as belonging to the M4 muscarinic receptor subtype. Naunyn-Schmiedeberg's Arch Pharmacol 341:Suppl. R80 (abstract) 